\title{
An After Tax Valuation of Debt Instruments
}

\author{
Charles Higgins ${ }^{*}$ \\ Department Finance/CIS, Loyola Marymount University, 1 LMU Dr, Los Angeles, CA \\ *Corresponding author: chiggins@lmu.edu
}

Received March 02, 2014; Revised March 11, 2014; Accepted March 16, 2014

\begin{abstract}
The net present value of any loan at its own discount rate is shown to be zero in both pre tax and after tax worlds. This allows separation from any investment net present value analysis. Further, it simplifies the analysis and it is argued is appropriate even in weighted average cost of capital scenarios wherein the cost of a loan has a marginal cost of capital equal to its own after tax discount rate and remains a zero in terms of its own net present value.
\end{abstract}

Cite This Article: Charles Higgins, “An After Tax Valuation of Debt Instruments.” Journal of Finance and Economics, vol. 2, no. 3 (2014): 67-69. doi: 10.12691/jfe-2-3-2.

The value of a debt instrument is:

$$
\mathrm{V}=\sum \mathrm{C}_{\mathrm{t}} /(1+\mathrm{k})^{\mathrm{t}}
$$

where $\mathrm{V}$ is the valuation, $\mathrm{C}_{\mathrm{t}}$ is the cash payment at time $\mathrm{t}$ from zero through terminal time period $\mathrm{T}$, and $\mathrm{k}$ is the discount rate. A bond or a similar interest only loan for time periods starting at one would be:

$$
\mathrm{B}=\Sigma \mathrm{iF} /(1+\mathrm{k})^{\mathrm{t}}+\mathrm{F} /(1+\mathrm{k})^{\mathrm{M}}
$$

where $B$ is the bond value, $i$ is the interest (coupon) rate on a bond or loan with a face value of $\mathrm{F}$ and a maturity of M. It is equivalent to:

$$
\mathrm{B}=(\mathrm{iF} / \mathrm{k})\left(1-1 /[1+\mathrm{k}]^{\mathrm{M}}\right)+\mathrm{F} /(1+\mathrm{k})^{\mathrm{M}} .
$$

If $\mathrm{i}$ equals $\mathrm{k}$ then $\mathrm{B}$ equals $\mathrm{F}$, or:

$$
\begin{aligned}
\mathrm{B} & =(\mathrm{kF} / \mathrm{k})\left(1-1 /[1+\mathrm{k}]^{\mathrm{M}}\right)+\mathrm{F} /(1+\mathrm{k})^{\mathrm{M}} \\
& =(\mathrm{F})\left(1-1 /[1+\mathrm{k}]^{\mathrm{M}}\right)+\mathrm{F} /(1+\mathrm{k})^{\mathrm{M}} \\
& =\mathrm{F}-\mathrm{F} /(1+\mathrm{k})^{\mathrm{M}}+\mathrm{F} /(1+\mathrm{k})^{\mathrm{M}}=\mathrm{F} .
\end{aligned}
$$

If interest payments are subject to a tax rate $\mathrm{x}$ and evaluated at an after tax discount rate of $k(1-x)$, then the valuation would be:

$$
\begin{aligned}
\mathrm{B}= & (\mathrm{iF}[1-\mathrm{x}] / \mathrm{k}[1-\mathrm{x}])\left(1-1 /[1+\mathrm{k}\{1-\mathrm{x}\}]^{\mathrm{M}}\right) \\
& +\mathrm{F} /(1+\mathrm{k}[1-\mathrm{x}])^{\mathrm{M}} .
\end{aligned}
$$

If the discount rate equals the after tax interest rate, then:

$$
\begin{aligned}
\mathrm{B}= & (\mathrm{kF}[1-\mathrm{x}] / \mathrm{k}[1-\mathrm{x}])\left(1-1 /[1+\mathrm{k}\{1-\mathrm{x}\}]^{\mathrm{M}}\right) \\
& +\mathrm{F} /(1+\mathrm{k}[1-\mathrm{x}])^{\mathrm{M}} \\
= & \mathrm{F}\left(1-1 /[1+\mathrm{k}\{1-\mathrm{x}\}]^{\mathrm{M}}\right)+\mathrm{F} /(1+\mathrm{k}[1-\mathrm{x}])^{\mathrm{M}} \\
= & \mathrm{F}-\mathrm{F} /(1+\mathrm{k}[1-\mathrm{x}])^{\mathrm{M}}+\mathrm{F} /(1+\mathrm{k}[1-\mathrm{x}])^{\mathrm{M}}=\mathrm{F} .
\end{aligned}
$$

Thus an after tax discount rate, derived from the marginal cost of a tax deductible loan, and which is used to value the loan will have an equivalent face value. Moreover, this allows the separation of the financing costs from the investment with the loan having a net present value of zero. That is, the net present value of a loan is the addition of the current receipt of funds at say time zero minus the present value of the later payments, or NPV $=$ $+\mathrm{F}-\mathrm{B}$. But if $\mathrm{i}$ equals $\mathrm{k}$, then the net present value is zero. Likewise, if the loan is tax deductible and evaluated at a like after tax discount rate, then the net present value remains zero and can be separated from project evaluation.

A fully amortized loan is where the present value of equal payments of $\mathrm{A}$ made through time to maturity $\mathrm{M}$ equals the face value, or:

$$
\mathrm{F}=\Sigma \mathrm{A} /(1+\mathrm{k})^{\mathrm{t}}=(\mathrm{A} / \mathrm{k})\left(1-1 /[1+\mathrm{k}]^{\mathrm{M}}\right) .
$$

A pure discount (zero coupon) instrument is where a single payment is made at maturity, or:

$$
\mathrm{B}=\mathrm{F} /(1+\mathrm{k})^{\mathrm{M}}
$$

while noting that tax regulations require a timely recognition of gain for each intervening time period even though there are no other cash payments. Further, both the pure discount and fully amortized instruments have tax payments that differ in each time period t. It can be shown that in both cases that the after tax valuations for each are equal to their nontaxable versions if discounted at their after tax discount rates equal to $\mathrm{k}(1-\mathrm{x})$. Consider a fully amortized loan of $\$ 1,000$ for 10 years at a 10 percent discount rate with a payment of $\$ 162.75$, a tax deductible rate of 40 percent, and evaluated at an after tax discount

\begin{tabular}{cccccc}
\multicolumn{6}{c}{ rate of 6 percent: } \\
\hline Year & Principal & Interest & Tax Credit & PV Credit & PV Payment \\
\hline 0 & 1000.00 & 0.00 & 0.00 & 0.00 & 0.00 \\
1 & 937.25 & 100.00 & 40.00 & 37.74 & 153.53 \\
2 & 868.23 & 93.73 & 37.49 & 33.37 & 144.84 \\
3 & 792.31 & 86.82 & 34.73 & 29.16 & 136.64 \\
4 & 708.80 & 79.23 & 31.69 & 25.10 & 128.91 \\
5 & 616.93 & 70.88 & 28.35 & 21.19 & 121.61 \\
6 & 515.88 & 61.69 & 24.68 & 17.40 & 114.73 \\
7 & 404.72 & 51.59 & 20.64 & 13.72 & 108.23 \\
8 & 282.45 & 40.47 & 16.19 & 10.16 & 102.11 \\
9 & 147.95 & 28.25 & 11.30 & 6.69 & 96.33 \\
10 & 0.00 & 14.80 & 5.92 & 3.30 & 90.88 \\
\hline
\end{tabular}


At an after tax rate of 6 percent, the present value of the tax credits equals $\$ 197.82$ and the present value of the payments equals $\$ 1,197.82$. Thus the present value of this $\$ 1,000$ fully amortized loan at its own after tax discount rate still equals $\$ 1,000$. The formulaic notation for the fully amortized loan is:

$$
\begin{aligned}
& \mathrm{F}=(\mathrm{A} / \mathrm{k})\left(1-1 /[1+\mathrm{k}]^{\mathrm{M}}\right) \\
& \text { or } \mathrm{A}=\mathrm{Fk} /\left(1-1 /[1+\mathrm{k}]^{\mathrm{M}}\right)
\end{aligned}
$$

and

$$
\mathrm{F}=\Sigma \mathrm{A} /(1+\mathrm{k})^{\mathrm{t}}
$$

and principal

$$
\mathrm{P}_{0}=\mathrm{F} \text { where } \mathrm{P}_{\mathrm{M}}=0 \text {, }
$$

but after tax

$$
\begin{aligned}
& \mathrm{V}=\Sigma \mathrm{xkP}_{\mathrm{t}-1} /(1+\mathrm{k}[1-\mathrm{x}])^{\mathrm{t}}-\Sigma \mathrm{A} /(1+\mathrm{k}[1-\mathrm{x}])^{\mathrm{t}} \\
& \text { where } \mathrm{P}_{\mathrm{t}}=\mathrm{P}_{\mathrm{t}-1}(1+\mathrm{k})-\mathrm{A}
\end{aligned}
$$

A pure discount (zero coupon) instrument is subject to taxable treatment (described as Original Issue Discount or OID) even though no other cash payments may occur during the intervening periods. Consider a payment of $\$ 1,000$ due in 10 years at a 10 percent interest rate. Its present value would be $\$ 385.55$. At a 40 percent tax rate OID present values discounted at 6 percent would be:

\begin{tabular}{ccccc}
\hline Year & Principal & Increase & Taxable & PV Tax \\
\hline 0 & 385.55 & 0.00 & 0.00 & 0.00 \\
1 & 424.10 & 38.55 & 15.42 & 14.55 \\
2 & 466.51 & 42.41 & 16.96 & 15.10 \\
3 & 513.16 & 46.65 & 18.66 & 15.67 \\
4 & 564.47 & 51.32 & 20.53 & 16.26 \\
5 & 620.92 & 56.45 & 22.58 & 16.87 \\
6 & 683.01 & 62.09 & 24.84 & 17.51 \\
7 & 751.31 & 68.30 & 27.32 & 18.17 \\
8 & 826.45 & 75.13 & 30.05 & 18.86 \\
9 & 909.09 & 82.64 & 33.06 & 19.57 \\
10 & 1000.00 & 90.91 & 36.36 & 20.31 \\
\hline
\end{tabular}

The total present value of the tax payments at the 6 percent after tax discount rate equals $\$ 172.85$. The original \$385.55 present value of $\$ 1,000$ due in 10 years reflects a 10 percent discount rate, but at a 6 percent after tax discount rate the $\$ 1,000$ equals $\$ 558.40$. However, the present value remains unchanged with the now higher present value of $\$ 558.40$ being offset by the present value of the OID tax obligations of $\$ 172.85$ which is $\$ 385.55$ and equals the original pre tax present value. The formulaic notation for the pure discount loan is:

$$
\mathrm{P}_{0}=\mathrm{F} /(1+\mathrm{k})^{\mathrm{M}}
$$

and where

$$
\mathrm{P}_{\mathrm{M}}=\mathrm{F}
$$

but after tax

$$
\begin{aligned}
\mathrm{V}= & \mathrm{F} /(1+\mathrm{k}[1-\mathrm{x}])^{\mathrm{M}} \\
& -\Sigma \mathrm{x}\left(\mathrm{P}_{\mathrm{t}}-\mathrm{P}_{\mathrm{t}-1}\right) /(1+\mathrm{k}[1-\mathrm{x}])^{\mathrm{t}}
\end{aligned}
$$

$$
\begin{gathered}
\mathrm{P}_{\mathrm{t}}=\mathrm{P}_{\mathrm{t}-1}(1+\mathrm{k}) \\
\mathrm{V}=\mathrm{F} /(1+\mathrm{k}[1-\mathrm{x}])^{\mathrm{M}}-\Sigma \mathrm{xkP}_{\mathrm{t}-1} /(1+\mathrm{k}[1-\mathrm{x}])^{\mathrm{t}}
\end{gathered}
$$

In summary, any net present value analysis that includes financing costs based upon a discount rate from its own loan unnecessarily complicates the analysis and moreover if the net effect upon present values is other than zero is also wrong. This is true in both the before tax and after tax worlds. Do note that weighted average costs of capital with financing sources other than loans could be different in consideration. Nevertheless, in more complex financings one could still regard the marginal cost of the loan at its own discount rate and could be separated from the net present value analysis in both pre tax and post tax worlds. Often lost is the fact that the discounting process indirectly captures the borrowing costs.

Introductory finance texts either: specifically exclude, ignore, or include financing costs in their presentation of net present value. It is argued here that while those finance texts that include interest expense in the net present value analysis is inappropriate, especially if the financing costs do not have a net present value of zero either before or after tax, and that those texts which merely ignore it in their discussions of (ir)relevant or incremental cash flows do little better. I've examined some four dozen various introductory finance texts I've received recently. Here are some texts which specifically exclude financing or interest costs from the net present value analysis:

Berk, Jonathan \& Peter DeMarzo \& Jarrad Harford Fundamentals of Corporate Finance Pearson Prentice Hall 2009

Brigham, Eugene F. \& Joel F. Houston Fundamentals of Financial Management: concise $4^{\text {th }}$ ed. Thomson South-Western 2004, p. 426, $5^{\text {th }}$ ed. 2007.

Brigham, Eugene F. \& Joel F. Houston Fundamentals of Financial Management $8^{\text {th }}$ ed. Thomson South-Western 2015.

Keown, Arthur J. \& John D. Martin \& J. William Petty Foundations of Finance $7^{\text {th }}$ ed. Pearson Prentice-Hall 2011, p. 308, $8^{\text {th }}$ ed. 2014.

Lasher William R. Practical Financial Management $7^{\text {th }}$ ed. South-Western.

Melicher, Ronald W. \& Edgar A. Norton Finance: Foundations of financial institutions and management 2007, p. 214.

Ross, Stephen A. \& Randolph W. Westerfield \& Bradford D. Jordan Fundamentals of Corporate Finance $10^{\text {th }}$ ed. McGraw-Hill 2011, p. 208.

Notably some texts have a discussion of foreign exchange rate risk in the net present value presentation but do broach the irrelevance of including interest payments; these include:

Besley, Scott \& Eugene F. Brigham Essentials of Managerial Management $14^{\text {th }}$ ed. Thomson SouthWestern 2008.

Brook, Raymond D. Financial Management: Core Concepts Pearson Prentice-Hall 2010, p. 559.

Emory, Douglas R. \& John D. Finnerty \& John D. Stowe Corporate Financial Management $3^{\text {rd }}$ ed. Pearson Prentice-Hall 2007, p. 829.

Gitman, Lawrence Principles of Managerial Finance $11^{\text {th }}$ ed. Pearson Addison-Wesley 2006, $12^{\text {th }}$ ed. 2009. 
Moyer, R. Charles \& James R. McGuigan \& William J. Kretlow Contemporary Financial Management $11^{\text {th }}$ ed. South-Western 2009.

Some texts go to great lengths to describe which cash flow to include/exclude but omit financing costs; these include:
Parrino, Robert \& David Kidwell, Thomas Bates Fundamentals of Corporate Finance $2^{\text {nd }}$ ed. Wiley 2012. And here are those texts which do include in my judgment incorrectly financing costs in their presentations of net present value:

Benninga, Simon Principles of Finance with Microsoft Excel $2^{\text {nd }}$ ed. Oxford University Press 2011, p. 152. 